\title{
CO HYDROGENATION AND ADSORPTION STUDIES ON SUPPORTED NICKEL SMSI CATALYSTS
}

TEXAS UNIV. AT AUSTIN. DEPT. OF CHEMISTRY

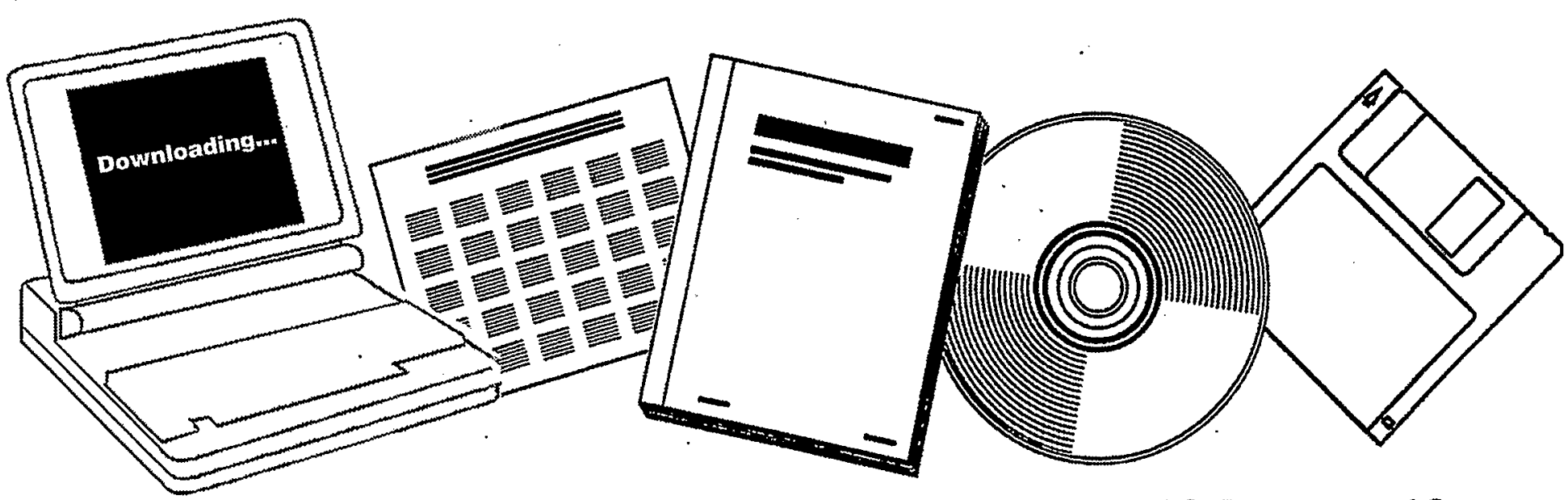

U.S. Department of Commerce National Technical Information Service 


\title{
CO Hydrogenation and Adsorption Studies on Supported-Nickel SMSI Catalysts
}

\author{
ShiU-Min Fang, $*, 1$ J. M. White, ${ }^{*}$ T. J. CAmpione, $t$ and John G. Ekerdt \\ * Department of Chemistry and + Department of Chemical Enginecring. University of Texas. \\ Austin, Texas 78712
}

Recèived December 6, 1983: revised March 15, 1985

The uptake of $\mathrm{CO}$ by $\mathrm{Ni}_{\mathrm{TiO}}{ }_{2}$ and $\mathrm{Ni}^{2} \mathrm{Ti}_{2} \mathrm{O}_{3}^{n}$ was investigated at 25 and $125^{\circ} \mathrm{C}$ following lowtemperature ( $\mathrm{LT}=250^{\circ} \mathrm{C}$ ) and high-temperature $\left(\mathrm{HT}=450^{\circ} \mathrm{C}\right.$ ) reduction. Infrared spectroscopy was used to identify the onset of nickel carbonyl $\left(\mathrm{Ni}(\mathrm{CO})_{4}\right)$ formation under various conditions of temperature and pressure. The $\mathrm{CO}$ uptake data were modeled using the Langmuir equation for isothermal adsorption. Monolayer coverages and equilibrium constants for $\mathrm{CO}$ adsorption were obtained from the uptake data. Carbon monoxide monolayer coverages were not affected by the reduction temperature of either $\mathrm{Ni} / \mathrm{TiO}_{2}$ or $\mathrm{Ni} / \mathrm{Ti}_{2} \mathrm{O}_{3}$. Methanation activity at $275^{\circ} \mathrm{C}$ was approximately a factor of 2 greater for the $\mathrm{Ni}^{2} \mathrm{TiO}_{2}$ (LT) than the $\mathrm{Ni} / \mathrm{TiO}_{i}$ (HT) catalyst. This correlated well with the relative strength of the $\mathrm{CO}$-metal surface bond, which also decreased by a factor of approximately 2 . These findings suggest that the enhanced methanation rate observed on $\mathrm{TiO}_{2}$ supported catalysts is not due to the presence or absence of a strong metal-support interaction condition of the $\mathrm{TiO}_{2}^{n}$ but to other properties of $\mathrm{TiO}_{2}$ as compared to other supports. 1985 Acadernic Pressi, Inc.

\section{INTRODUCTION}

The marked decrease in carbon monoxide and hydrogen chemisorption capacity and, in some cases, the vastly different catalytic properties of $\mathrm{TiO}_{2}$-supported group VIII transition metal catalysts have been topics of great interest since Tauster and co-workers reported a strong metal-support interaction (SMSI) in $1978(l)$. Initially. many models for the SMSI effect were put forward, but only recently has evidence been reported for the observed SMSI phenomenon on $\mathrm{TiO}_{2}$-supported nickel (24).

It has been shown that $\operatorname{TiO}_{x}(1<x<2)$ species are present on supported-nickel surfaces in the SMSI state $(3,4)$. Raupp and Dumesic (2) have demonstrated that adsorbed $\mathrm{TiO}_{x}$ gives rise to the reduced $\mathrm{CO}$ coverage over a nickel foil, a phenomenon characteristic of SMSI. Kao et al. (5) have

\footnotetext{
I Present address: Department of Chemistry, University of Pittsburgh. Pittsburgh. Pa. 15260.
}

demonstrated that extensive $\mathrm{Ni}$-titania interdiffusion takes place at temperatures as low as $300^{\circ} \mathrm{C}$. Taken together, these observations suggest that $\mathrm{TiO}_{s}$ migration to the surface of bulk Ni particles plays an important role in the SMSI phenomenon on $\mathrm{Ni}$ / $\mathrm{TiO}_{2}$.

The studies reported here were conducted to establish the correlation, if any, between the adsorptive and the catalytic properties of nickel supported on $\mathrm{TiO}_{2}$ and $\mathrm{Ti}_{2} \mathrm{O}_{3}$ reduced at low $\left(250^{\circ} \mathrm{C}\right)$ and high $\left(450^{\circ} \mathrm{C}\right)$ temperatures. $\mathrm{Ti}_{2} \mathrm{O}_{3}$ was chosen to test the importance of the bulk $\mathrm{Ti}^{3+}$ concentration, since reduced forms of titania are thought to play a role in the SMSI state.

\section{EXPERIMENTAL METHODS}

\section{Materials}

Catalysts were prepared by the impregnation method using reagent-grade $\mathrm{Ni}\left(\mathrm{NO}_{3}\right)_{2} \cdot 6 \mathrm{H}_{2} \mathrm{O}$ obtained from Fisher Scientific Company. The supports used in this work were $\mathrm{TiO}_{2}$ (Matheson, Coleman, \& All rights of reprenduction in any form reserved. 
Bell, Inc.; $75 \%$ anatase and $25 \%$ rutile; 10 $\mathrm{m}^{2} / \mathrm{g}$ ), and $\mathrm{Ti}_{2} \mathrm{O}_{3}$ (Alfa. Products; $5.4 \mathrm{~m}^{2} / \mathrm{g}$ ). The surface area was estimated by the BET method with $\mathrm{N}_{2}$ as the adsorbate. After impregnation, the samples were dried in air at $110-120^{\circ} \mathrm{C}$ for $2 \mathrm{hr}$ and then calcined in air at $450^{\circ} \mathrm{C}$ overnight. Nickel weight loading was $10 \%$ for all catalysts.

Ultrahigh-purity hydrogen $(99.999 \%$ ) was further purified by passing it through a Deoxo purifier (Matheson Corp.). Carbon monoxide ( $99.99 \%$ purity, Matheson) was passed through a molecular sieve trap at $155^{\circ} \mathrm{C}$ to remove any carbonyls. Helium ( $99.9999 \%$ purity) flowed through an alumina trap before use.

\section{Apparatus and Procedure}

Adsorption measurements were performed in a conventional glass vacuum system capable of achieving a dynamic vacuum of $10^{-5}$ Torr. Pressures were measured with a MKS Baratron capacitance manometer to determine the amount of CO adsorption.

Approximately $0.3 \mathrm{~g}$ of catalyst was placed in a Pyrex adsorption cell and evacuated while heating to $200^{\circ} \mathrm{C}$ for $45 \mathrm{~min}$ at a pressure of less than one millitorricelli. The catalyst was then reduced in situ for $2 \mathrm{hr}$ using 760 Tort hydrogen at either $250^{\circ} \mathrm{C}$ (LT) or $450^{\circ} \mathrm{C}$ (HT). During this period the $\mathrm{H}_{2}$ was changed three times. The temperature was then lowered to $200^{\circ} \mathrm{C}$ while evacuating for $30 \mathrm{~min}$ to a pressure of less than one millitorricelli.

$\mathrm{CO}$ uptäke stúdies were performed at 25 and $125^{\circ} \mathrm{C}$. Fifteen to thirty min were allowed for equilibrium before each new measurement. For the $25^{\circ} \mathrm{C}$ study, the dual-isotherm technique (6) was used to determine the amount of strongly held $\mathrm{CO}$ adsorbed at different coverages. Two isotherms were measured, with a brief evacuation between them, and then subtracted to account for only the strongly held species. At $125^{\circ} \mathrm{C}$, only one isotherm was measured for each catalyst since adsorption by the support materials was insignificant and $\mathrm{Ni}(\mathrm{CO})_{4}$ formation was strongly suppressed.

The procedures for IR experiments were similar to those reported in a previous paper from this laboratory (7). Infrared spectra were taken on a Nicolet 7199 FT-IR spectrometer and recorded in absorbance with $2 \mathrm{~cm}^{-1}$ resolution. Absorption due to the $\mathrm{CaF}_{2}$ windows, gas phase, and the disk background were subtracted. The catalyst disks, $20-30 \mathrm{mg} / \mathrm{cm}^{2}$, were pressed between two pieces of paraffin paper.

CO hydrogenation was carried out in a quartz, fixed-bed reactor operating in a differential mode at low conversions. Samples of $0.2-0.4 \mathrm{~g}$ were pretreated in situ in flowing $\mathrm{H}_{2}$ at either $250^{\circ} \mathrm{C}$ (LT) or $450^{\circ} \mathrm{C}$ (HT) for $2 \mathrm{hr}$. Reaction temperatures ranged from 200 to $300^{\circ} \mathrm{C}$. The reactant gas composition ranged from $3: 1$ to $15: 1\left(\mathrm{H}_{2}: \mathrm{CO}\right)$ and $C O$ pressures ranged from 0.05 to 0.25 atm; He was used to adjust the total pressure to $1 \mathrm{~atm}$. Space velocities were varied from 18,000 to $54,000 \mathrm{hr}^{-1}$ to maintain differential conditions. A procedure similar to that used by Sinfelt (8) was employed to maintain catalytic activity as the total time on-stream increased. This consisted of cyclic 30-min purges in pure $\mathrm{H}_{2}$ between 10min $\mathrm{H}_{2} / \mathrm{CO}$ exposures.

The details of the product analysis have been described elsewhere (9). A Varian 3700 gas chromatograph was used with two packed columns ( $\frac{1}{n}$ in. o.d. stainless-steel columns of Chromosorb 106 and 20\% OV101 on Chromosorb P-AW). Product gas concentrations were determined with a Hewlett-Packard-3390 A integrator by comparing the product peak areas to those for a standard mixture.

$X$-ray powder diffraction patterns were recorded by a General Electric Model XRD-5 diffractometer using $\mathrm{Cu}(\mathrm{K} \alpha)$ radiation. The average Ni particle size was estimated by $\mathrm{X}$-ray line broadening techniques. All the catalysts were prereduced in $\mathrm{H}_{2}$ and then exposed to air at room temperature. The calculated average particle size for each of the four catalysts was $20 \mathrm{~nm}$. 


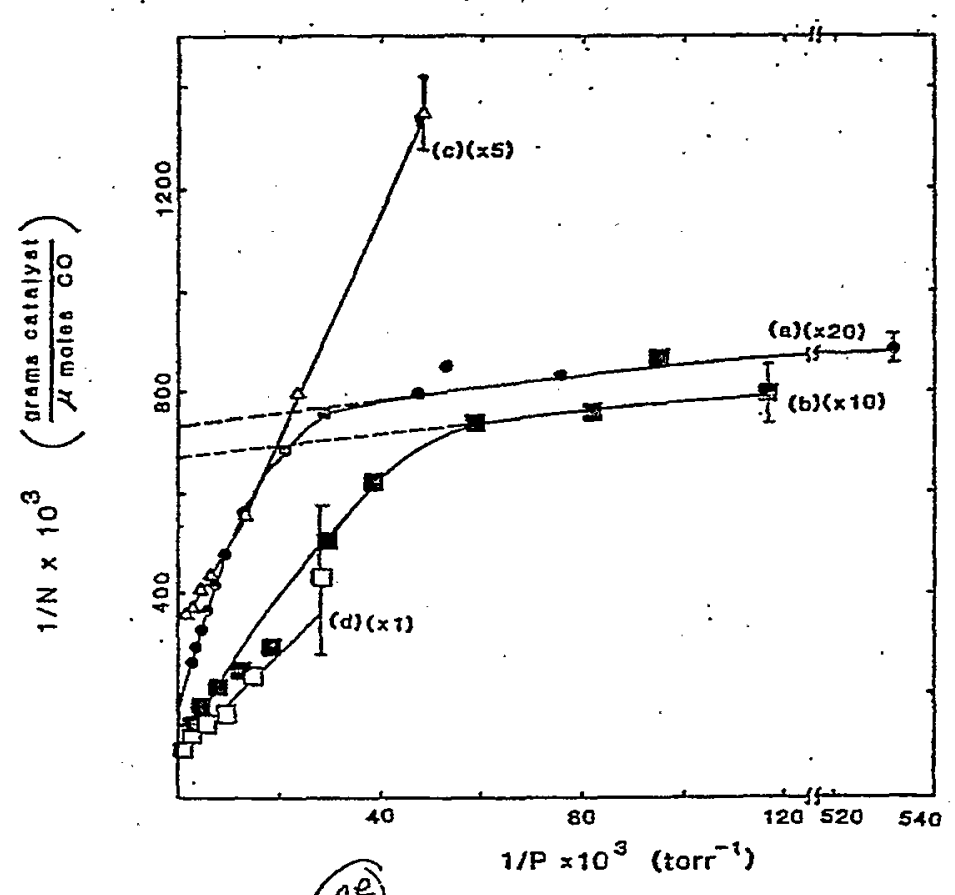

Fic. 1. Langmuir plots of the diffeferf isotherms for $\mathrm{CO}$ chemisorption at $25^{\circ} \mathrm{C}$ : (a) (ब) on $\mathrm{Ni} / \mathrm{TiO}_{2}$

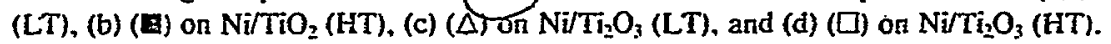

\section{RESULTS}

\section{Results at $25^{\circ} \mathrm{C}$}

The $\mathrm{CO}$ isotherms (dual and subtracted) at $25^{\circ} \mathrm{C}$ on $10 \% \mathrm{Ni} / \mathrm{TiO}_{2}$ (LT), (HT) and $10 \% \mathrm{Ni} / \mathrm{Ti}_{2} \mathrm{O}_{3}$ (LT), (HT) catalysts are shown in Fig. 1. To make comparisons, these results were all fit using the Langmuir model for associative adsorption:

$$
\frac{1}{N}=\frac{1}{N_{\mathrm{s}}}+\frac{1}{N_{\mathrm{s}} K_{\mathrm{CO}}} \frac{1}{P}
$$

where $N=$ moles of $\mathrm{CO}$ adsorbed/g catalyst, $N_{\mathrm{s}}=$ moles of $\mathrm{CO}$ adsorbed/g catalyst at saturation coverage, $K_{\mathrm{Co}}=$ equilibrium constant for $C O$ adsorption, and $P=$ gas phase pressure. Values for $N_{\mathrm{s}}$ for the $\mathrm{Ni}$ / $\mathrm{TiO}_{2}$ catalysts were determined by extrapolating the low-pressure linear section of the isotherms. The constants are listed in Table 1.

Hydrogen uptake values for each of the catalysts are presented in Table 1 . Since $\mathrm{H}_{2}$ adsorbs onto the surface dissociatively, sat- uration coverage values reflect the amount of atomic hydrogen adsorbed.

Infrared spectra for $\mathrm{CO}$ adsorption at $25^{\circ} \mathrm{C}$ on $\mathrm{Ni} / \mathrm{TiO}_{2}(\mathrm{LT})$ and (HT) are pre-

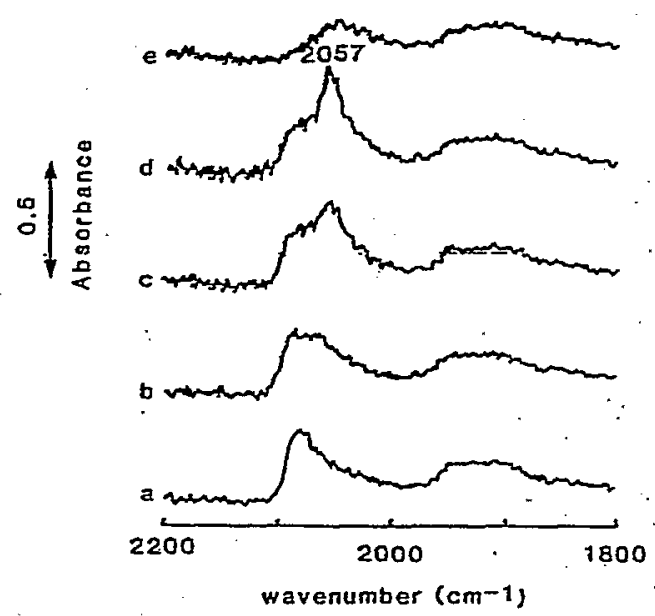

Fig. 2. IR spectra of $\mathrm{CO}$ chemisomtion on $\mathrm{Ni}^{\mathrm{T}} \mathrm{TiO}_{2}$ (LT) at $25^{\circ} \mathrm{C}$ : (a) $P_{\mathrm{CO}}=0.9 \mathrm{Torr}$, (b) $P_{\mathrm{Cn}}=65.9 \mathrm{Torr}$, (c) $P_{\mathrm{CO}}=284$ Torr, (d) $P_{\mathrm{co}}=418$ Torr, and (e) evacuation at $25^{\circ} \mathrm{C}$ for 5 min after (d). 
TABLE I

Uplake and Reaction Data

\begin{tabular}{|c|c|c|c|c|c|c|c|}
\hline & \multicolumn{3}{|c|}{ Co uptake } & \multirow{2}{*}{$\begin{array}{l}\mathrm{H}_{2} \text { uptake } \\
N_{6}{ }^{k}\left(2 S^{\circ} \mathrm{C}\right)\end{array}$} & \multirow{2}{*}{$\begin{array}{l}\text { Nir(CO) } \\
\text { formation } \\
\text { P(os rTorr) }\end{array}$} & \multicolumn{2}{|c|}{ Mettamation } \\
\hline & $N_{*} \times(25 \times C)$ & $N_{s}\left(125^{\circ} \mathrm{C}\right)$ & $x_{\mathrm{CO}} \times 10^{3}\left(123^{4} \mathrm{C}\right)$ & & & $\underset{\text { (kcal/mole) }}{E_{\text {mit }}}$ & $\begin{array}{c}\text { TON } \times 10^{2} \\
{\left[275^{\circ} \mathrm{C}\right]}\end{array}$ \\
\hline 10 uт $\mathrm{NiThO}_{2}(\mathrm{LT})$ & 26 & 26 & 238 & 78 & so & $33=2$ & 76 \\
\hline 10 wt. NiTTO: $(\mathrm{HTT})$ & 15 & 25 & 90 & 38 & 2000 & $33 \pm 2$ & 35 \\
\hline 10 utfic $\mathrm{Ni} / \mathrm{Ti}=\mathrm{O}_{3}$ (LT) & 15 & 9.5 & 48 & 14 & S013 & $37 \pm 2$ & 14 \\
\hline 10 WT' $\mathrm{NiT}_{2} \mathrm{O}_{3}$ (HT) & 125 & 8 & $2 i$ & 8 & r & $31 \pm 3$ & 27 \\
\hline
\end{tabular}

Sive. $N_{4}=\mu$ moles of gas adsorted per gram of nickel catulyst at saturation coverage. TON $=$ moles of $\mathrm{CH}_{4}$ formed per secund per active nickel site. based on $\mathrm{CO}$ uptake at $125^{\circ} \mathrm{C}$.

- Measured using the dual-isotherm technique.

- Based on the adsorption of atomic hydrogen.

c Nickel eabonyl (Ni(CO)s) was not observed to form at $125^{\circ} \mathrm{C}$ and $P_{\mathrm{CO}}$ up to $550 \mathrm{Tom}$.

sented in Figs. 2 and 3. Notice that in the $\mathrm{Ni} / \mathrm{TiO}_{2}$ (LT) study, a significant amount of the $\mathrm{CO}$ in the $2030-2090 \mathrm{~cm}^{-1}$ range (linearly bonded, subcarbonyl or carbonyl $\mathrm{CO}$ $(10-12))$ is removed by a brief evacuation (compare curves (d) and (e)), but that the intensity of the lower wavenumber, more strongly held bridge-bonded CO (1875-1960 $\left.\mathrm{cm}^{-1}(10-12)\right)$ is undiminished. Also note the development of the distinctive nickel carbonyl band at $-2057 \mathrm{~cm}^{-1}(12-15)$ as the CO pressure is increased. This band was observed on the catalyst surface as well as in the gas phase. The IR spectra for the Ni/ $\mathrm{TiO}_{2}$ (HT) case (Fig. 3) also demonstrates that the species giving rise to the band at $2050-2085 \mathrm{~cm}^{-1}$ is removed by a brief evacuation (compare curves $(b)$ and (c)).

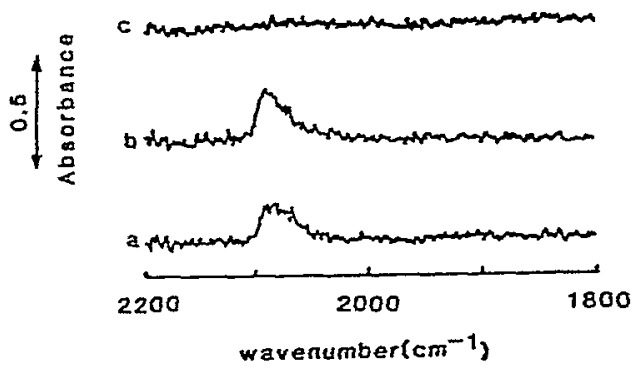

FIG. 3. IR spectra of $\mathrm{CO}$ chemisorption on $\mathrm{Ni} / \mathrm{TIO}_{2}$ (HT) at $25^{\circ} \mathrm{C}:$ (a) $P_{\text {co }}=0.3$ Torr, (b) $P_{\text {Co }}=10 \mathrm{TorT}$, and (c) evacuation at $25^{\circ} \mathrm{C}$ for $5 \mathrm{~min}$ after exposure to $P_{\text {co }}$ of 368 Torr.

\section{Results at $125^{\circ} \mathrm{C}$}

Langmuir iṣotherms were used to model the adsorption of $\mathrm{CO}$ at $125^{\circ} \mathrm{C}$ and are presented in Figs. 4 and 5 . Uptake for pure $\mathrm{TiO}_{2}$ and $\mathrm{Ti}_{2} \mathrm{O}_{3}$ at this temperature was negligible; therefore only one series of uptake measurements was performed on each catalyst. Since this procedure did not involve an evacuation step, the resultant data account for both strongly and weakly adsorbed $\mathrm{CO}$. Table $\mathrm{I}$ includes $N_{\mathrm{s}}$ and $K_{\mathrm{CO}}$ values for this series of experiments.

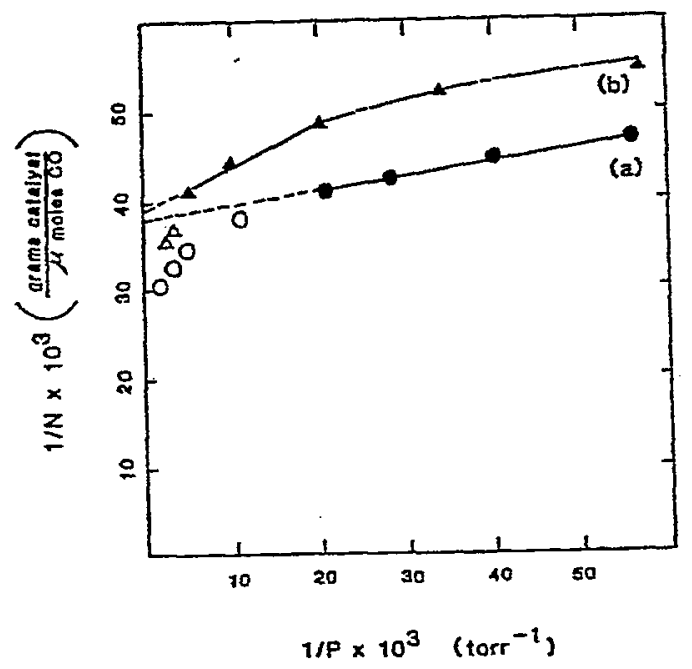

FtG. 4. Langmuir plots for CO chemisorption at $125^{\circ} \mathrm{C}$ : (a) (O) on $\mathrm{Ni} / \mathrm{TiO}_{1}(\mathrm{LT})$ and $(b)(\Delta)$ on $\mathrm{Ni} / \mathrm{TrO}_{2}$ (HT). (The open symbols (O and $\Delta$ ) correspond to uptake measurements influenced by the formation of $\mathrm{Ni}(\mathrm{CO})_{4}$. The solid lines represent approximations to the slope of the isotherms.) 


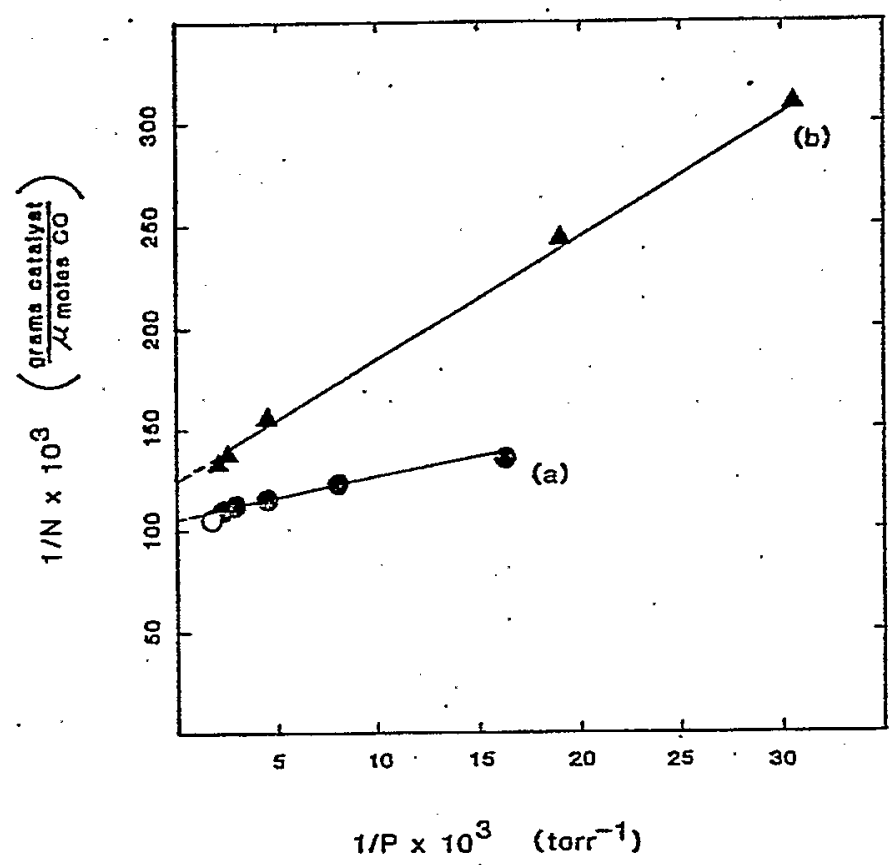

Fig. 5. Langmuir plots for $\mathrm{CO}$ chemisorption at $125^{\circ} \mathrm{C}:(a)(\theta)$ on $\mathrm{Ni} / \mathrm{Ti}_{2} \mathrm{O}_{3}(\mathrm{LT})$ and (b) (A) on $\mathrm{Ni} /$ $\mathrm{Ti}_{2} \mathrm{O}_{3}$ (HT). (The open symbol (O) corresponds to the uptake measurement influenced by the formation of $\left.\mathrm{Ni}(\mathrm{CO})_{4-}\right)$

The open symbols in Figs. 4 and 5 represent data infuenced by the formation of $\mathrm{Ni}(\mathrm{CO})_{4}$. Infrared techniques were used to verify the onset of carbonyl formation corresponding to the departures from linearity in the isotherm data. The minimum pressures at which the incipient formation of $\mathrm{Ni}(\mathrm{CO})_{4}$ occurred on each of the catalysts are listed in Table 1.

In order to determine whether $\mathrm{CO}$ disproportionation or $\mathrm{Ni}(\mathrm{CO})_{4}$ formation would be a problem if the uptake studies were performed at $125^{\circ} \mathrm{C}$, an infrared study was undertaken on the $\mathrm{Ni} / \mathrm{TiO}_{2}$ (LT) catalyst. Stretching frequencies for $\mathrm{CO}_{2}(\sim 2330$ $\left.\mathrm{cm}^{-1}\right)$ and $\mathrm{Ni}(\mathrm{CO})_{4}\left(2057 \mathrm{~cm}^{-1}\right)$ were not observed at 400 Tor of $\mathrm{CO}$. Evidence for linear and bridge-bonded chemisorbed $\mathrm{CO}$ was found in the absorbances centered at 2050 and $1915 \mathrm{~cm}^{-1}$, respectively.

\section{Methanation Activity}

The kinetic data for $\mathrm{CO}$ methanation on $\mathrm{Ni} / \mathrm{Ti}_{2} \mathrm{O}_{3}(\mathrm{LT})$, (HT) are listed in Table 1 .
Methanation studies were performed at $275^{\circ} \mathrm{C}$ using a $\mathrm{H}_{2} / \mathrm{CO}$ ratio of $3: 1$. Tumover numbers (TON's) were defined as the number of moles of $\mathrm{CH}_{4}$ formed per second per active $\mathrm{Ni}$ site for $\mathrm{CO}$ chemisorption at $125^{\circ} \mathrm{C}$ (i.e., $N_{s}$ at $125^{\circ} \mathrm{C}$ ). Activation energies for methanation were calculated from the rate data and are included in Table 1 (last two columns).

\section{DISCUSSION}

At room temperature, the tendency for $\mathrm{Ni}(\mathrm{CO})_{4}$ to form when a supported-nickel catalyst is exposed to carbon monoxide is well documented $(12,14,16,17)$. Even though carbonyl formation on $\mathrm{Ti}_{x} \mathrm{O}_{y}$-supported nickel is somewhat suppressed in comparison to $\mathrm{Ni} / \mathrm{SiO}_{2}$ or $\mathrm{Ni} / \mathrm{Al}_{2} \mathrm{O}_{3}(18)$, it remains a problem in obtaining accurate $\mathrm{CO}$ uptake data and infrared spectra of chemisorbed $\mathrm{CO}$. The IR data in Fig. 2 for $\mathrm{CO}$ uptake at $25^{\circ} \mathrm{C}$ on $10 \%$. $\mathrm{Ni} / \mathrm{TiO}_{2}$ catalysts clearly indicates the formation of $\mathrm{Ni}(\mathrm{CO})_{4}$ as $\mathrm{CO}$ pressure is increased. This is respon- 
sible for the significant departure from linearity of the isotherms for the $\mathrm{Ni} / \mathrm{TiO}_{2}$ (LT) and (HT) catalysts (see Fig. I), even though the dual-isotherm technique of Yates and Sinfelt (6) was used. With this method, a brief evacuation between the collection of data for the two isotherms is used to remove weakly bound species. Apparently $\mathrm{Ni}\left(\mathrm{CO}_{4}\right)$ effects were not completely removed by the application of this technique and uptake results were adversely affected. In addition to influencing uptake results, $\mathrm{Ni}(\mathrm{CO})_{4}$ formation may strip the catalyst surface of nickel and redistribute it on the infrared cell or on the catalyst itself. Thus, the formation of $\mathrm{Ni}(\mathrm{CO})_{4}$ should be avoided if possible.

The dual-isotherm technique also assumes that only weakly held $\mathrm{CO}$ (mainly on the support) is removed during the evacuation step (I). However, our infrared evidence (Fig. 2) shows that a significant amount of chemisorbed $\mathrm{CO}$ is removed from the metal. For weakly adsorbing catalysts (as reffected by a relatively low value of $K_{\mathrm{CO}}$ ) such as $\mathrm{Ni} / \mathrm{TiO}_{2}$ (HT) and $\mathrm{Ni} / \mathrm{Ti}_{2} \mathrm{O}_{3}$ (LT) and (HT), a brief evacuation may remove the majority of the $\mathrm{CO}$ initially adsorbed on the metal. Therefore, another technique was sought that would accurately measure $\mathrm{CO}$ uptake and account for both the strongly and weakly chemisorbed $\mathrm{CO}$.

It was with this motivation that singleisotherm adsorption studies were conducted at $125^{\circ} \mathrm{C}$, a temperature at which. thermodynamically, $\mathrm{Ni}(\mathrm{CO})_{4}$ formation is suppressed to a tolerable level and at which $\mathrm{CO}$ dissociation is not a problem. This was verified using IR spectroscopy. No infrared stretching frequencies for $\mathrm{CO}_{2}$ (indicating $\mathrm{CO}$ dissociation) or $\mathrm{Ni}(\mathrm{CO})_{4}$ were observed at $125^{\circ} \mathrm{C}$ and $\mathrm{CO}$ pressures up to 400 Torr. The onset of carbonyl formation was determined by noting deviations from linearity in the uptake isotherms (see Figs. 4 and 5). It was also determined that adsorption of $\mathrm{CO}$ by the pure support material was negligible at $125^{\circ} \mathrm{C}$.

Using the $125^{\circ} \mathrm{C}$ single-isotherm uptake technique, it was possible to obtain accurate values for the equilibrium constant for CO adsorption $\left(K_{\mathrm{CO}}\right)$ and saturation coverage numbers $\left(N_{s}\right)$ which accounted for the adsorption of both strongly and weakly held $\mathrm{CO}$.

$K_{\mathrm{CO}}$ can be thought of as a relative mieasure of the average strength of CO-metal bonding; the larger $K_{\mathrm{CO}}$, the more strongly the CO molecule is held to the surface. It is evident from Table 1 that there is a trend of decreasing $K_{\mathrm{CO}}$ as one progresses from $\mathrm{TiO}_{2}-$ to $\mathrm{Ti}_{2} \mathrm{O}_{3}$-based catalysts. For the $\mathrm{TiO}_{2}$-supported cases, the results are in agreement with the work by Raupp and Dumesic (2), Jiang et al. (16), and Vannice and Garten (18), who found that the strength of the metal-CO bond is significantly weakened on $\mathrm{TiO}_{2}$-supported catalysts in the SMSI state. This trend, however, is not reflected-in the saturation coverage values $\left(N_{\mathrm{s}}\right)$. In fact, $N_{\mathrm{s}}$ values at $125^{\circ} \mathrm{C}$ for $\mathrm{Ni} / \mathrm{TiO}_{2}$ (LT) and (HT) and for $\mathrm{Ni} / \mathrm{Ti}_{2} \mathrm{O}_{3}$ (LT) and (HT) are approximately equal. This is surprising since it has been reported that $\mathrm{H}_{2}$ and $\mathrm{CO}$ uptake at $25^{\circ} \mathrm{C}$ are suppressed on $\mathrm{Ni} / \mathrm{TiO}_{2}(3,16,18,19,20)$.

In light of the above discussion we believe that significant amounts of weakly chemisorbed $\mathrm{CO}$ may have been overlooked. All of the procedures in question included an evacuation step which can lead to the underestimation of the amount of $\mathrm{CO}$ adsorbed. For example, compare $N_{\mathrm{s}}\left(25^{\circ} \mathrm{C}\right)$ to $N_{\mathrm{s}}\left(125^{\circ} \mathrm{C}\right)$ for $\mathrm{Ni}^{2} / \mathrm{TiO}_{2}$ (LT) and (HT) (Table 1). Particulariy for the (HT) data, the $25^{\circ} \mathrm{C}$ estimates are too low because, as indicated in the IR data (Figs. 2 and 3), a significant amount of the total adsorbed $\mathrm{CO}$ was removed by evacuation. In the (LT) case, bridge-bonded $\mathrm{CO}\left(1875-1960 \mathrm{~cm}^{-1}\right)$ is not removed and the linear-bonded CO (2030$2090 \mathrm{~cm}^{-1}$ ) is only partially removed by the evacuation step. Thus, the monolayer coverage values compare favorably. The amount of chemisorbed CO may also be underestimated in work done using high-vacuum photoelectron and Auger spectroscpies where a catalyst surface is dosed with 
$\mathrm{CO}$ and then evacuated before any measurements are taken (see, for example, the Auger work by Takatani and Chung (3)). Our $125^{\circ} \mathrm{C}$ uptake studies provide no evidence for the suppression of $\mathrm{CO}$ uptake (i.e., $N_{s}$ ) on the $\mathrm{Ti}_{x} \mathrm{O}_{y}$-supported catalysts, even though $K_{\mathrm{CO}}$ values for the (LT) and (HT) cases differ by a factor of 2 or more.

A correlation was found between the relative value of $K_{\mathrm{CO}}$ for each of the catalysts and the onset of. $\mathrm{Ni}(\mathrm{CO})_{4}$ formation. As the strength of $\mathrm{CO}$ adsorption decreases and the overall intensity of the $\mathrm{CO}$ stretching frequency shifts to higher wavenumbers, the propensity for nickel carbonyl formation decreases. This is in agreement with the work of Jiang et al. (16) and Raupp and Dumesic (2).

For the titania-based systems studied here, there was no correlation between the $\mathrm{CH}_{4}$ turnover number (TON) and either $N_{\mathrm{S}}$ or $K_{\mathrm{CO}}$. However, we did find a significant decrease in the TON for $\mathrm{Ni}^{\mathrm{TiO}}{ }_{2}$ (HTT) (SMSI state) as compared to $\mathrm{Ni} / \mathrm{TiO}_{2}$ (LT) (non-SMSI state), in agreement with the findings of Burch and Flambard (2I) and with single crystal studies by Chung $e t$ al. (4). This suggests that the enhanced methanation activity of $\mathrm{Ni} / \mathrm{TiO}_{2}$ over $\mathrm{Ni} / \mathrm{SiO}_{2}$ (TON $=3$ orders of magnitude less) (2I) is a characteristic of $\mathrm{Ti}_{x} \mathrm{O}_{y}$-supported metals in general and not the direct consequence of an SMSI effect. Finally, it is clear that the presence of bulk $\mathrm{Ti}^{3+}$ does not enhance methanation activity since the $\mathrm{Ni} / \mathrm{Ti}_{2} \mathrm{O}_{3}$ TONs were significantly lower than those for $\mathrm{Ni} / \mathrm{TiO}_{2}$.

\section{CONCLUSIONS}

(1) The enhanced methanation activity of $\mathrm{Ni} / \mathrm{TiO}_{2}$ is not strongly correlated to the presence of an SMSI condition.

(2) The effect of (HT) reduction (SMSI) of $\mathrm{Ni} /$ titania catalysts is described better in terms of the strength of $\mathrm{CO}$ and $\mathrm{H}_{2}$ adsorption rather than in terms of the irihibition of the chemisorption of these molecules.
(3) Techniques involving an èvacuation procedure to determine the amount and/or strength of chemisorbed $\mathrm{CO}$ on a supported-metal catalyst surface should not be used unless it is verified that the weakly held $\mathrm{CO}$, removed from the surface during the evacuation step, does not desorb from metal sites. Such a procedure will underestimate the number of active metal surface sites.

(4) Bulk $\mathrm{Ti}^{3+}$ does not enhance the methanation activity.

(5) Nickel carbonyl formation on the Ni/ $\mathrm{Ti}_{x} \mathrm{O}_{y}$ catalysts studied is inhibited as the strength of the $\mathrm{CO}$-nickel surface bond decreases.

\section{ACKNOWLEDGMENTS}

This work was supported in part by the Office of Naval Research (JMW) and the National Science Foundation, Grant CPE-8319494 (JGE). ' .

\section{REFERENCES}

I. Tauster, S. J., Fung, S. C., and Garten. R. L., J. Amer. Chem. Soc. 100, 170 (1978).

2. Raypp, G. B., and Dumesic, J. A... J. Phys. Chem. 88,660 (1984).

3. Takatani, S., and Chung, Y.-W., J. Catal. 90, 75 (1984).

4. Chung, Y.-W., Xiong, G., and Kao, C. C.. J. Catal. 85, 237 (1984).

5. Kao, C. C., Tsai, S. C., Bahl, M. K., Chung. Y.W, and Lo, W. J., Surf. Sci. 95, 1 (1980).

6. Yates, D. J. C., and Sinfelt, J. H., J. Catul. 8, 348 (1967).

7. Tanaka, K., and White, J. M., J. Catal. 79, 81 (1983).

8. Sinfelt, J. H., Chem. Eng. Sci. 23, 1181 (1968).

9. Wang, C. J., and Ekerdt, J. G., J. Catal. 89, 172 (1983).

10. Primet, M., Daimon, J. A., and Marin. G. A.. J. Catal. 46, 25 (1977).

II. Rochester, C. H., and Terrell, R. J.. J. Chem. Soc. Faraday Trans. I 73, 609 (1977).

12. Yates, J. T., and Gariand, C. W., J. Phys. Chem. $65,617(1961)$.

13. Ludlum, K. H., and Eischens. R. P.. Surf. Sci. 40, 397 (1973).

14. Feal, M. J.. Leisegang, E. C., and Torrington. R. G., I. Catal. 42, 10 (1976).

15. Van Hardeveld, R.. and Hartog. F.. “Advances in 
Catalysis." Vol. 22, p. 75, 1972; "Proceedings, 4th International Congress on Catalysis, Moscow, 1968" (B. A. Kazansky, Ed.). Adler, New York, 1968.

16. Jiang, X.-Z., Hayden, T. F., and Dumesic, J. A., J. Catal. 83, 168 (1983).

17. Bartholomew, C. Fi., and Pannell, R. B., J. Catal. 65,390 (1980).
18. Vannice, M. A., and Garten, R. L., J. Catal. 56, 236 (1979).

19. Smith, J. S., Thrower, P. A., and Vannice, M. A., J. Catal. 68, 270 (1981).

20. Bartholomew, C. H., Pannell, R. B., and Butler. J. L., J. Catal. 65, 335 (1980),

21. Burch, R., and Flambard, A. R., J. Catul. 78, 389 (1982).

This is a technical report per Dr. David Nelson, ONR/Code 413 


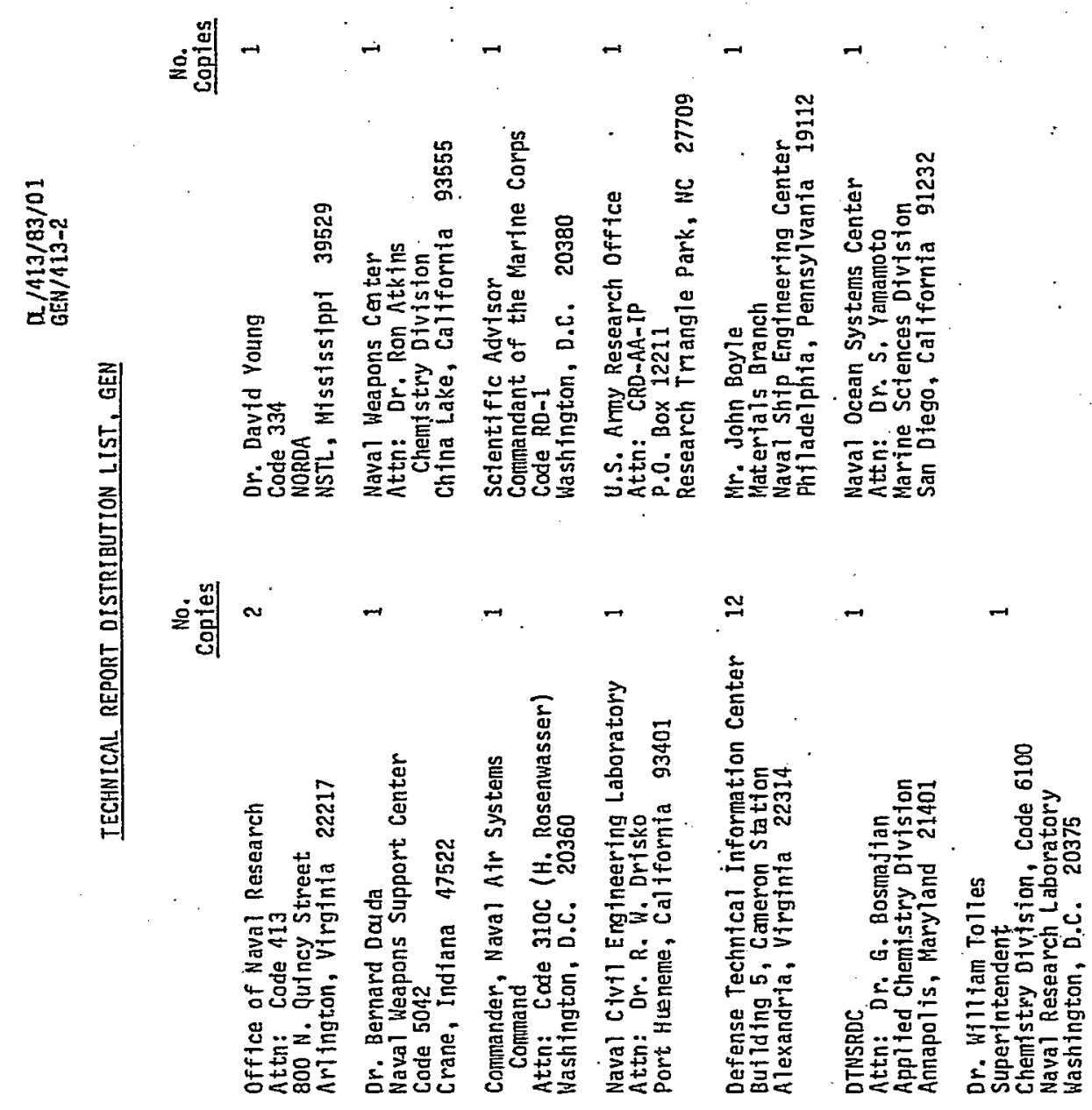




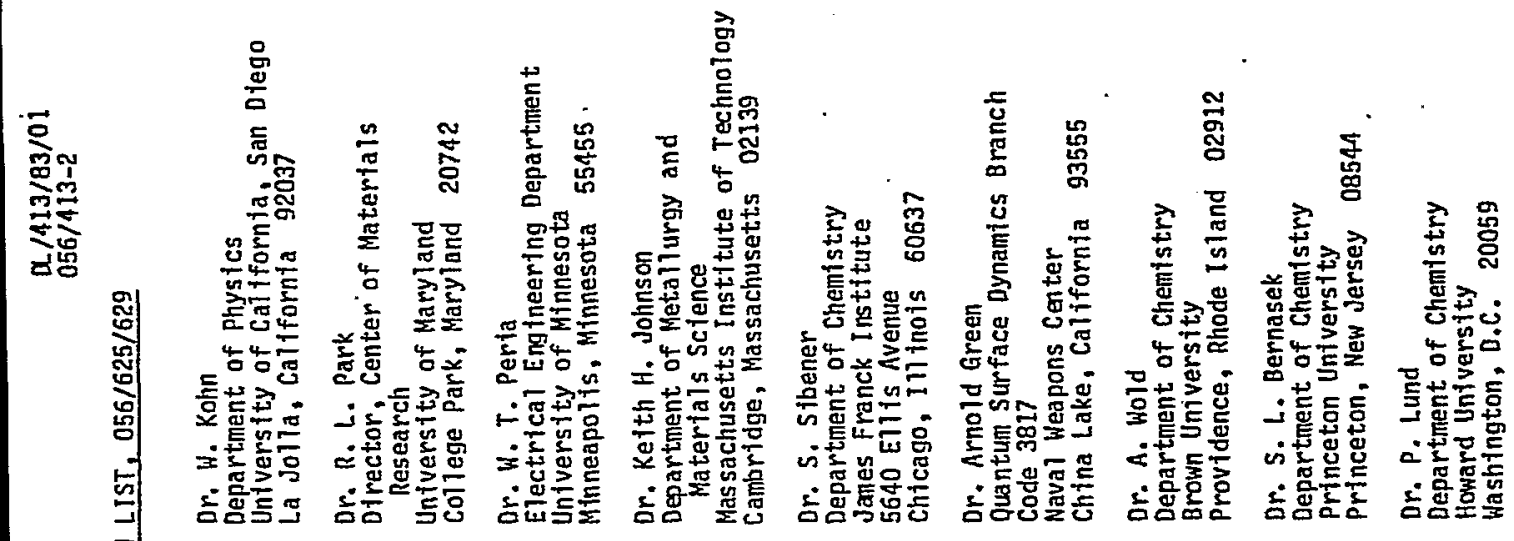

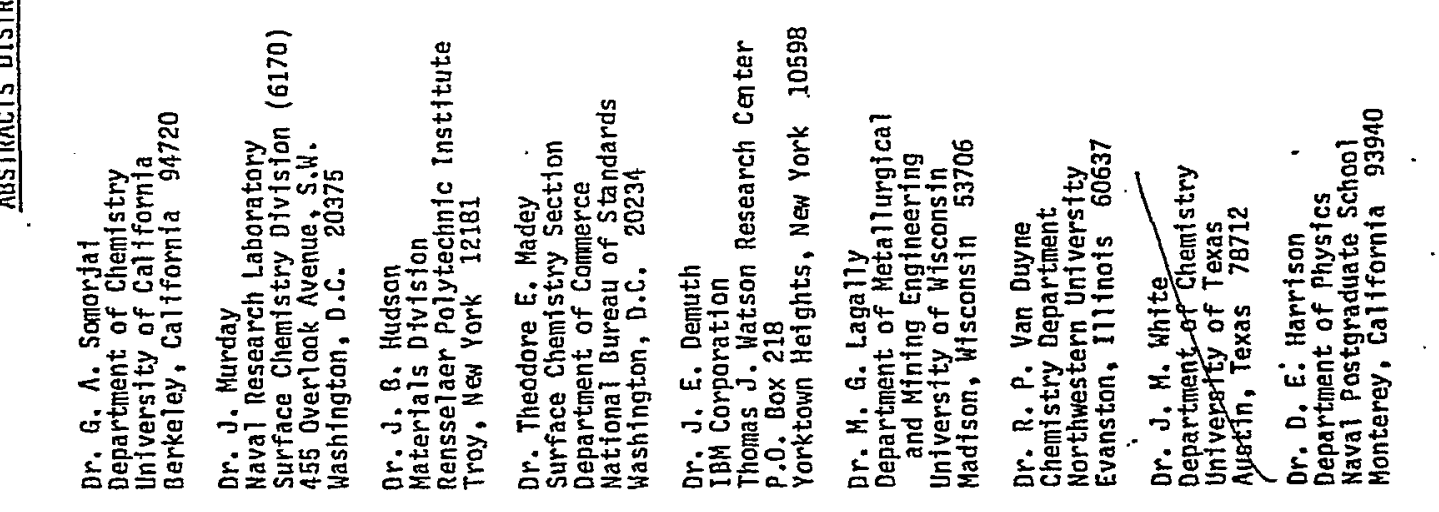

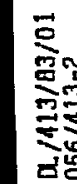

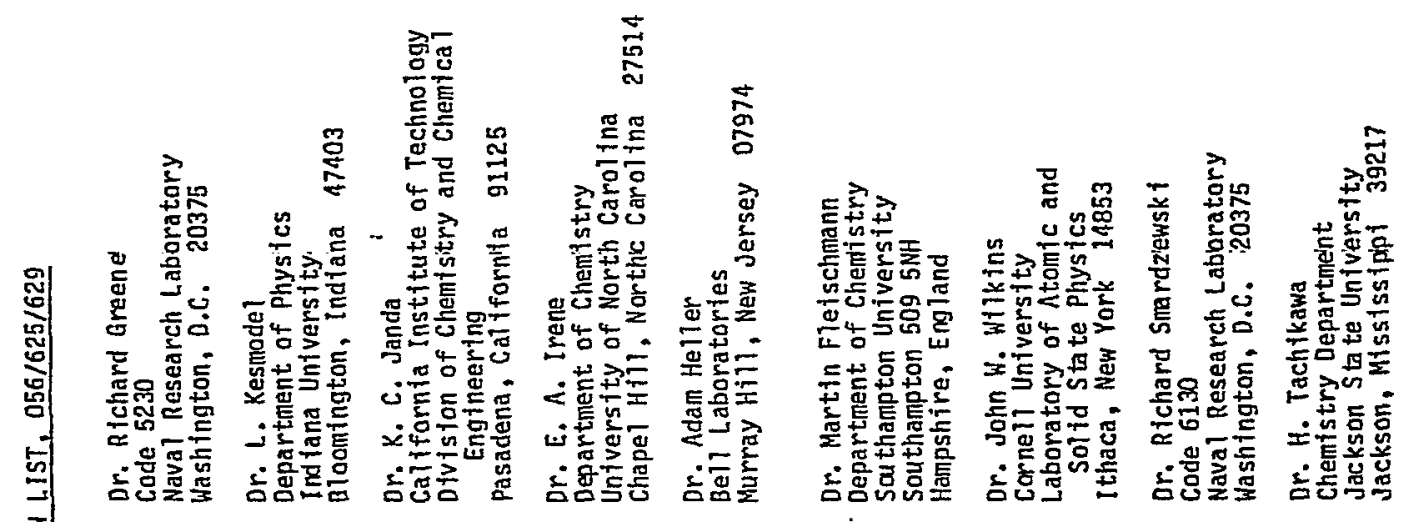



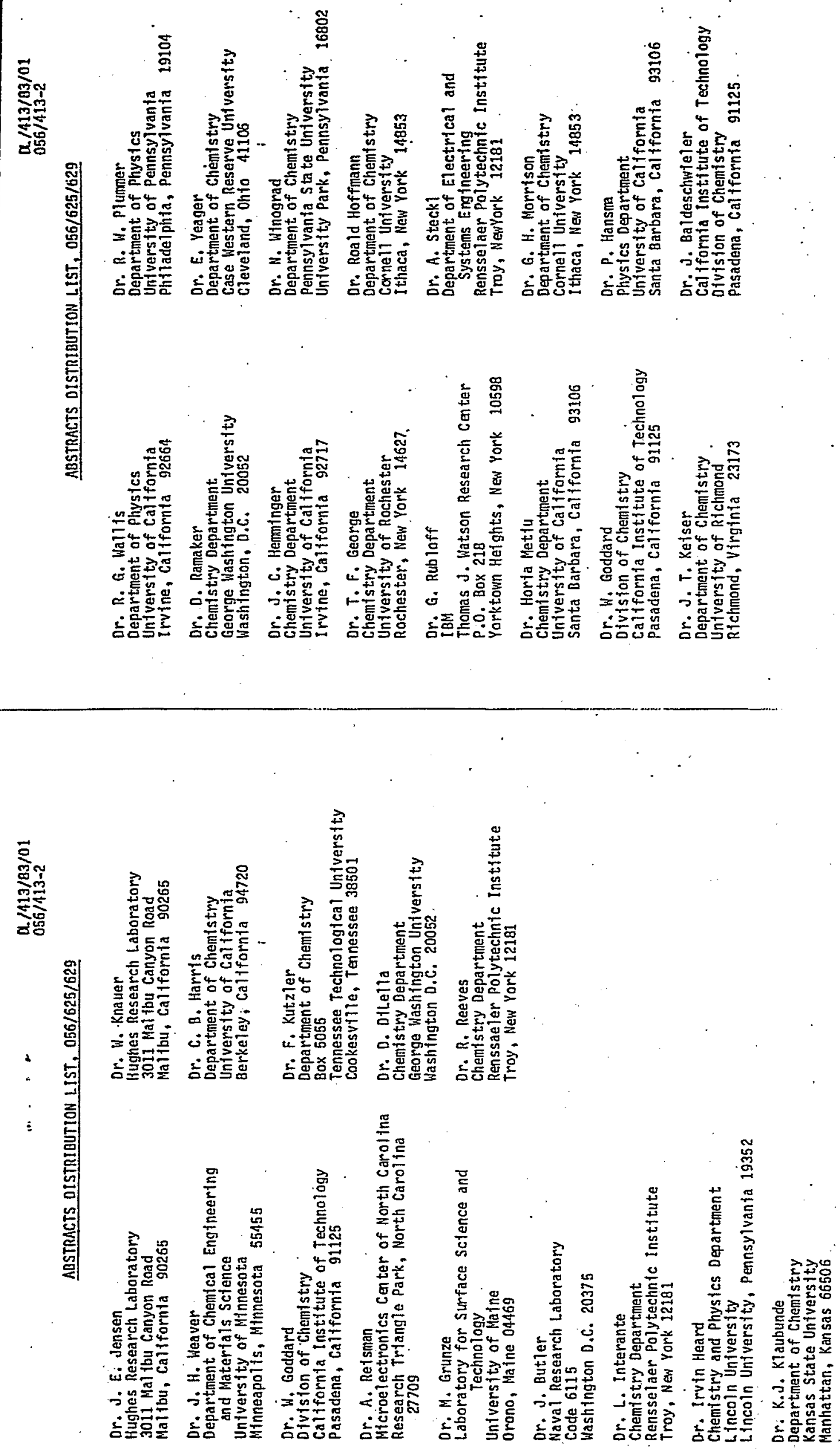


\begin{tabular}{|c|c|}
\hline & \\
\hline UसEEค & \\
\hline $\begin{array}{l}\text { TOTLE (ard Subtile) } \\
\text { Supported NickeI SMSI Catalysts }\end{array}$ & 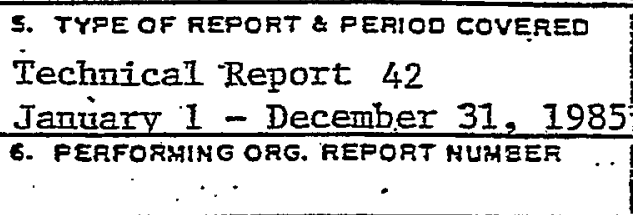 \\
\hline $\begin{array}{l}\text { AUTHOR(a) } \\
\text { SHiu-Min Fang, J. M. White, T. Campione and } \\
\text { J. G. Ekerdt. }\end{array}$ & $\begin{array}{l}\text { 8. COATRACT OR GRANT AL } \\
\text { N000014-83-K-0582 }\end{array}$ \\
\hline 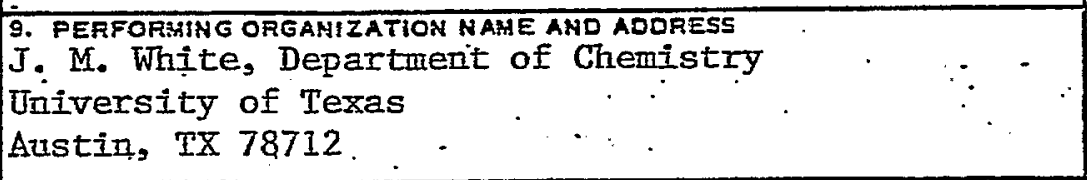 & $\begin{array}{l}\text { O. PROGRAHELEA } \\
\text { AREA \& WRK } \\
\text { Project No. }\end{array}$ \\
\hline 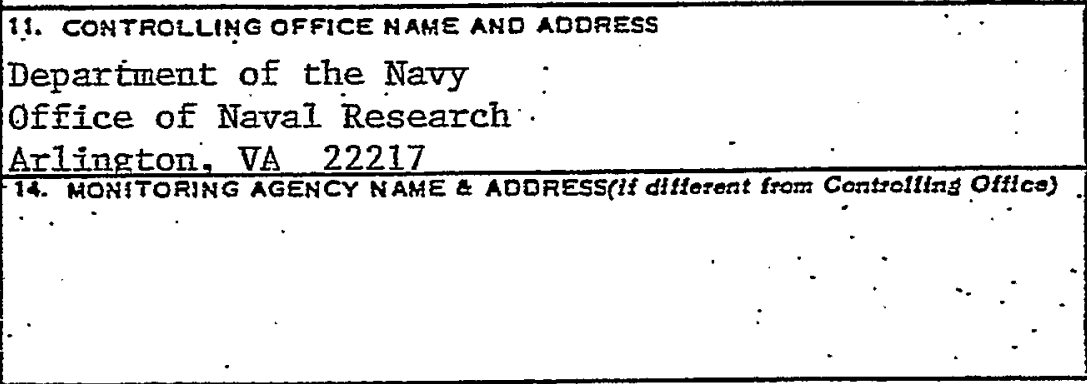 & 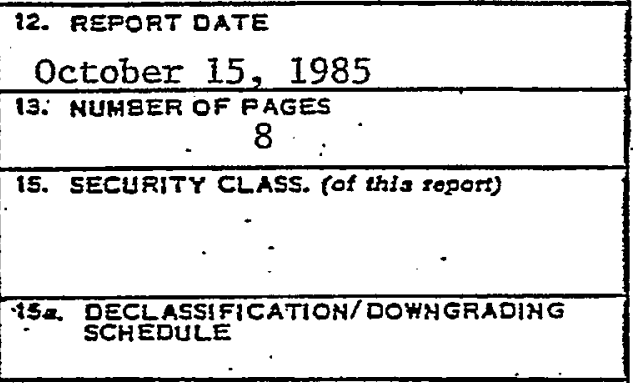 \\
\hline 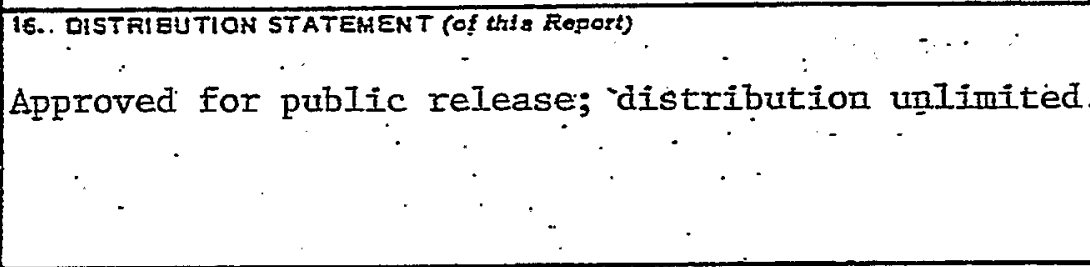 & $\cdots$ \\
\hline EEAENT (of the ebatract entes & (epport) \\
\hline $\begin{array}{c}\text { 8.. SUPFL EMENTARY HOTES } \\
\text { Journal of Catalysis (in press) }\end{array}$ & $\overline{-}$ \\
\hline revereo efide if necoesery and ldentffy by block numb & 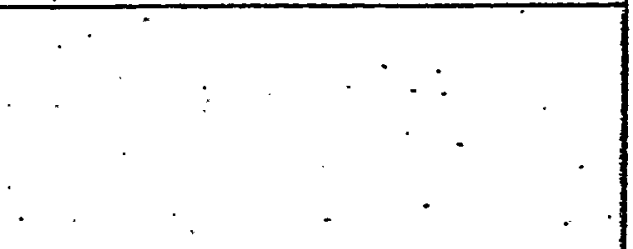 \\
\hline \multicolumn{2}{|c|}{ 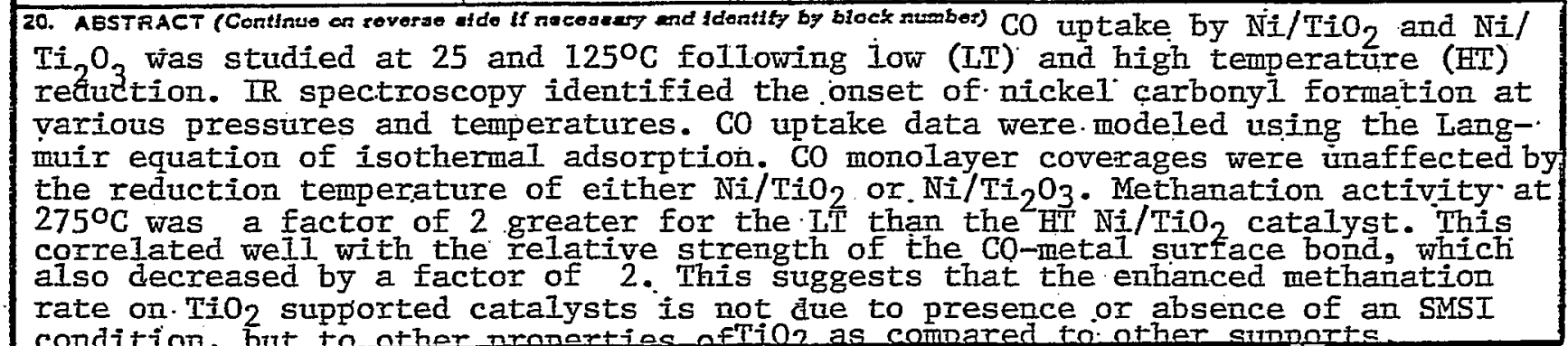 } \\
\hline
\end{tabular}

